\title{
Selective palladium-catalyzed amination of the heterocyclic core of variolins
}

\author{
Alejandro Baeza, Carolina Burgos, ${ }^{*}$ Julio Alvarez-Builla and Juan J. Vaquero* \\ Departamento de Química Orgánica, Universidad de Alcalá, 28871 Alcalá de Henares, Madrid, Spain
}

Received 4 December 2006; revised 30 January 2007; accepted 2 February 2007

Available online 7 February 2007

\begin{abstract}
A new and selective palladium-catalyzed amination of the pyrido $\left[3^{\prime}, 3^{\prime}: 4,5\right]$ pyrrolo[1,2- $\left.c\right]$ pyrimidine nucleus, the heterocyclic core of the variolin alkaloids, is described. The method allows the introduction of amino and aryl- and alkylamino substituents on the C9 position in advanced precursors of variolin B and deoxyvariolin.
\end{abstract}

(c) 2007 Published by Elsevier Ltd.

Variolins (1) are a group of marine heterocyclic substances isolated from the Antarctic sponge Kirkpatrickia variolosa $a^{1,2}$ and they have a common and rare tricyclic pyrido $\left[3^{\prime}, 3^{\prime}: 4,5\right]$ pyrrolo[1,2-c]pyrimidine (2) skeleton (Fig. 1).

An important feature of these compounds is the significant and differential cytotoxic activity against P-388 murine leukemia cells. In addition, recent studies have indicated that variolin B appears to act as a cyclindependent kinase inhibitor (CDK) and induces the activation of $\mathrm{p} 53$, although its pro-apoptotic activity is p53-independent and it is thus potentially active against
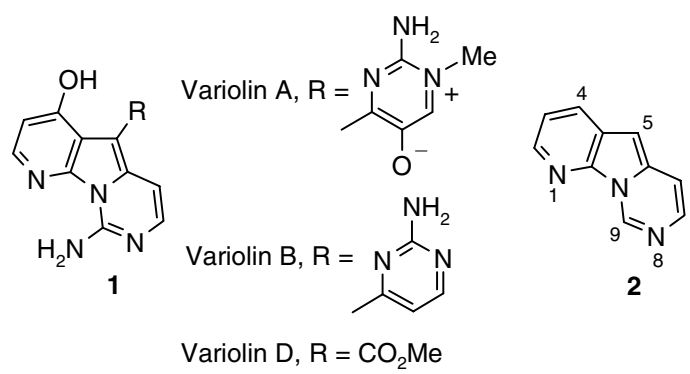

Figure 1. Variolins (1) and structure for pyrido $\left[3^{\prime}, 3^{\prime}: 4,5\right]$ pyrrolo $[1,2-c]-$ pyrimidine nucleus 2 .

Keywords: Pyrido[3 $\left.3^{\prime}, 3^{\prime}: 4,5\right]$ pyrrolo[1,2-c]pyrimidine; $N$-Tosylmethyl dichloroformimide; Amination; Palladium-catalyzed; Variolins.

* Corresponding authors. Tel.: +34 91885 4761; fax: +34 918854886 (J.J.V.); e-mail addresses: juanjose.vaquero@uah.es; juanjose@uah. es tumors with mutation or deletion of the p53 gene. ${ }^{3}$ Consequently, several groups have been involved in the synthesis of the core variolin heterocyclic system and/or total synthesis of variolin B. ${ }^{4}$ However, the reported methods employed in the synthesis of the pyrido $\left[3^{\prime}, 3^{\prime}: 4,5\right]$ pyrrolo $[1,2-c]$ pyrimidine nucleus scarcely explored the introduction of chemical diversity at the C9 position of this tricyclic system.

We report here a new approach to a conveniently C9substituted pyrido $\left[3^{\prime}, 3^{\prime}: 4,5\right]$ pyrrolo[1,2-c]pyrimidine derivative that allows the functionalization of this position with different alkyl- and arylamino substituents by applying palladium-promoted $\mathrm{C}-\mathrm{N}$ bond formation to this heterocyclic system.

Our first approach to the azolopyrimidine nucleus involved the reaction of bromomethylazoles 3 with tosylmethyl isocyanide (TosMIC) (4) (Scheme 1). ${ }^{5}$ This method implicates the nucleophilic displacement of the bromo-substituent, rearrangement of the methoxycarbonyl group, cyclization of the azole nitrogen on the isocyanide group and elimination of the $p$-toluenesulfinic

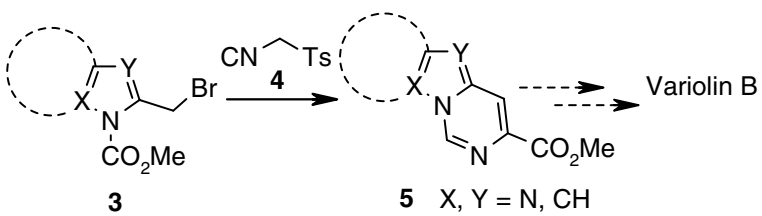

Scheme 1. Synthesis of azolopyrimidines from bromomethylazoles (3) and TosMIC (4). 
acid and has proven to be very efficient for the synthesis of a wide variety of azolopyrimidines $\mathbf{5}$, including the variolin core. However, this approach suffers from the drawback associated with the introduction of the amino substituent in the $\mathrm{C} 9$ position.

Starting from a suitable bromomethylazole,${ }^{5 \mathrm{~b}}$ we envisaged an alternative strategy to build C9-substituted pyrido $\left[3^{\prime}, 3^{\prime}: 4,5\right]$ pyrrolo $[1,2-c]$ pyrimidines using the TosMIC synthetic equivalent represented by $N$-tosylmethyl dichloroformimide (6). ${ }^{6}$ Two bromomethylpyridopyrroles $(\mathbf{3 a}, \mathbf{b})$ were chosen as model substrates to test the heterocyclization reaction, which should afford the corresponding advanced precursors for variolin B and its deoxy analogue (Scheme 2).

Initial results from the reaction of 3a under the same phase-transfer conditions used for the synthesis of $\mathbf{5}$ afforded 7 in $43 \%$ yield (Table 1, entry 1). In the search for the optimal conditions it was observed that compound 7 was not formed on using higher concentrated $\mathrm{NaOH}(30 \%)$ and the unexpected compound 8 was isolated in 5\% yield. This result was very convenient in terms of our ultimate goal, the total synthesis of variolin, since it circumvents the need to remove the methoxycarbonyl group. Consequently, we studied this heterocyclization process further in order to find a set of appropriate conditions to obtain $\mathbf{8}$ in a synthetically useful yield.

Representative results are summarized in Table 1 and show that phase-transfer conditions are necessary for a successful heterocyclization $^{5 b}$ (Table 1, entry 4). The best results (58\% yield) were obtained in the two-phase system $\mathrm{LiOH}(30 \%) / \mathrm{CH}_{2} \mathrm{Cl}_{2}$, with tetrabutylammonium chloride $(\mathrm{TBACl})$ as the catalyst at room temperature (Table 1, entry 7). The use of a less lipophilic base such as $\mathrm{NaOH}$ and/or other phase-transfer catalysts (Table 1, entries 5 and 8) did not improve the yield. Under these optimal conditions compound $\mathbf{9}$ was obtained from $\mathbf{3 b}$ in $53 \%$ yield. $^{7}$

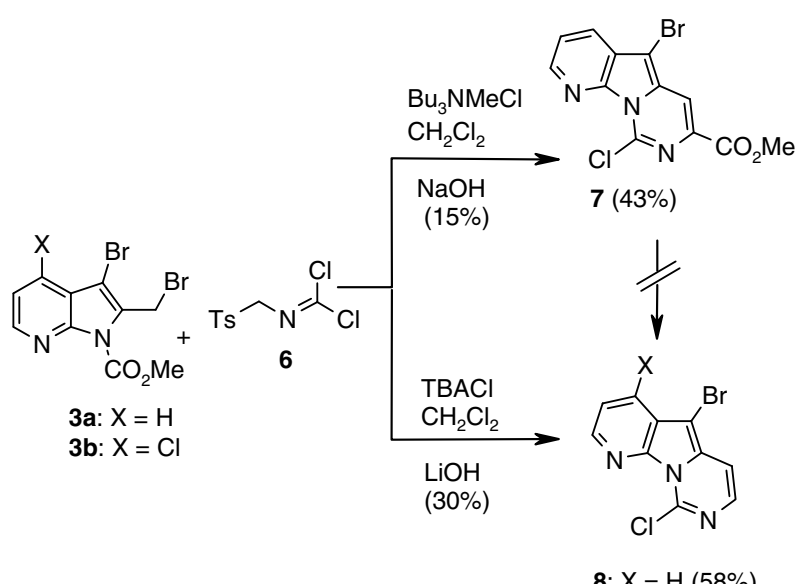

8: $\mathrm{X}=\mathrm{H}(58 \%)$

9: $\mathrm{X}=\mathrm{Cl}(53 \%)$

Scheme 2. 9-Chloropyrido[ $\left[3^{\prime}, 3^{\prime}: 4,5\right]$ pyrrolo[1,2-c]pyrimidines from 3 and $\mathrm{N}$-tosylmethyl dichloroformimide (6).
Table 1. Optimization of conditions for 8 from $3 \mathbf{a}$ and $\mathbf{6}$

\begin{tabular}{lllll}
\hline Entry & Catalyst & Base & $\begin{array}{l}\text { 7 Yield } \\
(\%)\end{array}$ & $\begin{array}{l}\mathbf{8} \text { Yield } \\
(\%)\end{array}$ \\
\hline 1 & $\mathrm{Bu}_{3} \mathrm{NMeCl}(10 \%)$ & $\mathrm{NaOH}(15 \%)$ & 43 & - \\
2 & $\mathrm{Bu}_{3} \mathrm{NMeCl}(10 \%)$ & $\mathrm{NaOH}(30 \%)$ & - & 5 \\
3 & $\mathrm{Bu}_{3} \mathrm{NMeCl}(10 \%)$ & $\mathrm{NaOH}(50 \%)$ & - & - \\
4 & - & $\mathrm{DBU}^{\mathrm{a}}$ & - & - \\
5 & $\mathrm{Bu}_{3} \mathrm{NMeCl}(10 \%)$ & $\mathrm{LiOH}(30 \%)$ & & 53 \\
6 & $\mathrm{TEBACl}(10 \%)$ & $\mathrm{LiOH}(30 \%)$ & 43 \\
7 & $\mathrm{TBACl}(10 \%)$ & $\mathrm{LiOH}(30 \%)$ & 58 \\
8 & Aliquat $(10 \%)$ & $\mathrm{LiOH}(30 \%)$ & 53 \\
\hline
\end{tabular}

${ }^{\mathrm{a}} \mathrm{Et}_{3} \mathrm{~N}$ and $\mathrm{Et}\left(i_{\mathrm{Pr}}\right)_{2} \mathrm{~N}$ were also tested resulting in the decomposition of $\mathbf{6}$ and recovering of $\mathbf{3 a}$.

While the formation of 7 can be explained for a similar mechanism to that proposed for the reaction 3a and TosMIC, ${ }^{5 \mathrm{a}, \mathrm{d}}$ the formation of $\mathbf{8}$ and $\mathbf{9}$ likely involves nucleophilic substitution of $\mathbf{6}$ on the bromomethylpyrrole 3a, deprotection of the azolic pyrrole under the phase-transfer conditions, cyclization by attack of the pyrrole nitrogen on the chloroimine and 1,2-elimination of $p$-toluenesulfinic acid. Support for this mechanism was found in the unsuccessful attempts to transform 7 into 8 under the reaction conditions (Scheme 2).

In order to explore the usefulness of $\mathbf{8}$ and $\mathbf{9}$ intermediates in the synthesis of variolin B, deoxyvariolin B, and various analogues, we tried to convert them into the amino derivatives 10a and 11a by simple nucleophilic displacement of the chloro atom in the C9 position. Different experiments were carried out on $\mathbf{8}$ in the presence of ammonium hydroxide and aliphatic and aromatic amines but this substitution reaction proved to be inappropriate for our purposes, with substitution products formed in very low yields. These results led us to turn our attention to the palladium-promoted $\mathrm{C}-\mathrm{N}$ bond formation developed by Buchwald and Hartwig. ${ }^{8}$

Our initial results showed that $\mathbf{8}$ can be converted selectively into 9 -aminopyrido[ $\left[3^{\prime}, 3^{\prime}: 4,5\right]$ pyrrolo[1,2-c]pyrimidine (10a) using triphenylsilylamine $\left(\mathrm{Ph}_{3} \mathrm{SiNH}_{2}\right)$ as an ammonia equivalent in the presence of LiHMDS using $2 \mathrm{~mol} \%$ of tris(dibenzylideneacetone)dipalladium $(0)$ $\left(\mathrm{Pd}_{2}(\mathrm{dba})_{3}\right)$ and $4 \mathrm{~mol} \%$ of (2-biphenyl)di-tert-butylphosphine. ${ }^{9}$ The best yield $(89 \%)$ was obtained using a slight excess of LiHMDS (1.2 equiv) and $\mathrm{Ph}_{3} \mathrm{SiNH}_{2}$ (1.2 equiv) in THF at room temperature ( $16 \mathrm{~h}$ ) or under reflux $(12 \mathrm{~h}) .{ }^{10}$ Further evidence of the selectivity of this reaction was obtained with 4,5,9-trihalo-substituted substrate $\mathbf{9}$, which was transformed selectively into $\mathbf{1 1 a}^{10}$ in $71 \%$ yield under the same conditions as used for 10a (Table 2, entry 2).The scope of this amination reaction was studied with aromatic, heteroaromatic, and aliphatic (primary and secondary) amines with both $\mathbf{8}$ and 9; the results obtained are shown in Table 2. ${ }^{11}$ The best results were obtained in THF using $\mathrm{Pd}(\mathrm{OAc})_{2} / 2$-di-tert-butylphosphinobiphenyl in the presence of $\mathrm{NaO} t-\mathrm{Bu}$. The scope of this palladium-catalyzed amination is considerably broader at $65^{\circ} \mathrm{C}$ than at room temperature, with very similar results on both heterocyclic substrates. 
Table 2. 9-Aminosubstituted derivatives $\mathbf{1 0}$ and $\mathbf{1 1}$<smiles>[X]c1ccnc2c1c(Br)c1ccnc(Cl)n12</smiles>

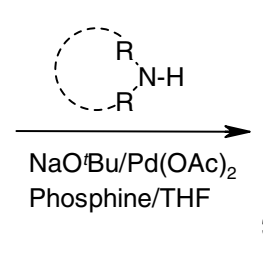<smiles>[X]c1ccnc2c1c(Br)c1ccnc(N3CCCCCC3)n12</smiles>

10: $\mathrm{X}=\mathrm{Cl}$
11: $\mathrm{X}=\mathrm{H}$

11: $X=H$

\begin{tabular}{|c|c|c|c|c|}
\hline Entry & Starting material $(\mathbf{8} / \mathbf{9})$ & Amine & Product $(\mathbf{1 0} / \mathbf{1 1})$ & Yield $^{\mathrm{a}}(\%)$ \\
\hline $\begin{array}{l}1 \\
2\end{array}$ & $\begin{array}{l}8 \\
9\end{array}$ & $\mathrm{Ph}_{3} \mathrm{SiNH}_{2}$ & & $\begin{array}{l}\text { 10a: } X=H, 89^{b} \\
\text { 11a: } X=C l, 71^{b}\end{array}$ \\
\hline $\begin{array}{l}3 \\
4\end{array}$ & $\begin{array}{l}8 \\
9\end{array}$ & & & $\begin{array}{l}\text { 10b: } X=\mathrm{H}, 90 \\
\text { 11b: } X=\mathrm{Cl}, 74\end{array}$ \\
\hline 5 & 8 & & & 10c: 75 \\
\hline $\begin{array}{l}6 \\
7\end{array}$ & $\begin{array}{l}8 \\
9\end{array}$ & & & $\begin{array}{l}\text { 10d: } X=\mathrm{H}, 90 \\
\text { 11d: } X=\mathrm{Cl}, 83\end{array}$ \\
\hline $\begin{array}{l}8 \\
9\end{array}$ & $\begin{array}{l}8 \\
9\end{array}$ & & & $\begin{array}{l}\text { 10e: } X=H, 61 \\
\text { 11e: } X=\mathrm{Cl}, 58\end{array}$ \\
\hline $\begin{array}{l}10 \\
11\end{array}$ & $\begin{array}{l}8 \\
9\end{array}$ & & & $\begin{array}{l}\text { 10f: } X=H, 67 \\
\text { 11f: } X=\mathrm{Cl}, 63\end{array}$ \\
\hline 12 & 8 & & & 10g: 58 \\
\hline 13 & 8 & & & 10h: 80 \\
\hline
\end{tabular}


Table 2 (continued)

\begin{tabular}{|c|c|c|c|c|}
\hline Entry & Starting material $(\mathbf{8} / \mathbf{9})$ & Amine & Product $(\mathbf{1 0} / \mathbf{1 1})$ & Yield $^{\mathrm{a}}(\%)$ \\
\hline 14 & 8 & & & 10i: 73 \\
\hline $\begin{array}{l}15 \\
16\end{array}$ & $\begin{array}{l}8 \\
9\end{array}$ & & & $\begin{array}{l}\text { 10j: } \mathrm{X}=\mathrm{H}, 72 \\
\text { 11j: } \mathrm{X}=\mathrm{Cl}, 78\end{array}$ \\
\hline 17 & 8 & & & 10k: 40 \\
\hline 18 & 8 & & & 10I: $X=H, 31$ \\
\hline 19 & 9 & $r \pi$ & & 11l: $\mathrm{X}=\mathrm{Cl}, 35$ \\
\hline 20 & 8 & & & 10m: $X=H, 0$ \\
\hline 21 & 9 & & & 11m: $\mathrm{X}=\mathrm{Cl}, 0$ \\
\hline
\end{tabular}

${ }^{a}$ All reactions were carried out in the presence of (2-biphenyl)di-tert-butylphosphine.

${ }^{\mathrm{b}}$ Reaction conditions: LiHMDS/THF $\mathrm{Pd}_{2}(\mathrm{dba})_{3} /(2$-biphenyl)di-tert-butylphosphine.

Aromatic primary amines such as aniline and heteroaromatic amines on $\pi$-deficient heterocycles (aminopyridines) produced good yields of products with both tricylic substrates 8 and 9 (Table 2, entries 3-7) while only moderate yields were obtained with 3 -aminopyrazole (Table 2, entries 8 and 9). In general, aliphatic primary and secondary amines afforded lower yieldsespecially in the case of secondary acyclic amines, which led to low yields (Table 2, entries 18 and 19) or did not afford the amination products with either 8 or 9 , even at high reaction temperatures and/or with larger amounts of catalyst (Table 2, entries 20 and 21).

In conclusion, a selective palladium-catalyzed amination reaction allowed the introduction of aryl- and alkylamino-substituents on the C9 position of the pyrido$\left[3^{\prime}, 3^{\prime}: 4,5\right]$ pyrrolo[ $[1,2-c]$ pyrimidine system, the heterocyclic core of the variolin alkaloids. Moreover, this method is also appropriate to prepare the 5-bromoand 5-bromo-4-chloro-9-aminoderivatives, both ad- vanced precursors of deoxyvariolin and variolin B, respectively.

\section{Acknowledgments}

We acknowledge financial support from the Spanish Ministerio de Educación y Ciencia (project CTQ2005/ 011060), Comunidad de Madrid (CAM) and Universidad de Alcalá (UAH) (project CAM/UAH-2005/044) and a grant (A.B.) from the Ministerio de Educación y Ciencia.

\section{References and notes}

1. Perry, N. B.; Ettouati, L.; Litaudon, M.; Blunt, J. W.; Munro, M. H. G.; Parkin, S.; Hope, H. Tetrahedron 1994, 50, 3987-3992. 
2. Trimurtulu, G.; Faulkner, D. J.; Perry, N. B.; Ettouati, L.; Litaudon, M.; Blunt, J. W.; Munro, M. H. G.; Jameson, G. B. Tetrahedron 1994, 50, 3993-4000.

3. (a) Yin, J.; Avilés, P.; Ly, C.; Lee, W.; Guillén, M. J.; Munt, S.; Cuevas, C.; Faircloth, G. J. Chromatogr. B 2006, 832, 268-273; (b) Fresneda, P. M.; Delgado, S.; Francesch, A.; Manzanares, I.; Cuevas, C.; Molina, P. J. Med. Chem. 2006, 49, 1217-1221; (c) Simone, M.; Erba, E.; Damia, G.; Vikhanskaya, F.; Di Francesco, A. M.; Riccardi, R.; Bailly, C.; Cuevas, C.; Fernandez SousaFaro, J. M.; D'Incalci, M. Eur. J. Cancer 2005, 41, 23662377; (d) Fernández, D.; Ahaidar, A.; Danelón, G.; Cironi, P.; Marfil, M.; Pérez, O.; Cuevas, C.; Albericio, F.; Joule, J. A.; Álvarez, M. Monatsh. Chem. 2004, 135, 615-627.

4. (a) Anderson, R. J.; Hill, J. B.; Morris, J. C. J. Org. Chem. 2005, 70, 6204-6212; (b) Karpov, A. S.; Merkul, E.; Rominger, F.; Müller, T. J. J. Angew. Chem., Int. Ed. 2005, 44, 6951-6956; (c) Ahaidar, A.; Fernández, D.; Danelón, G.; Cuevas, C.; Manzanares, I.; Albericio, F.; Joule, J. A.; Álvarez, M. J. Org. Chem. 2003, 68, 1002010029; (d) Ahaidar, A.; Fernández, D.; Pérez, O.; Danelón, G.; Cuevas, C.; Manzanares, I.; Albericio, F.; Joule, J. A.; Álvarez, M. Tetrahedron Lett. 2003, 44, 61916194; (e) Molina, P.; Fresneda, P. M.; Delgado, S. J. Org. Chem. 2003, 68, 489-499; (f) Molina, P.; Fresneda, P. M.; Delgado, S.; Bleda, J. A. Tetrahedron Lett. 2002, 43, 1005-1007; (g) Anderson, R. J.; Morris, J. C. Tetrahedron Lett. 2001, 42, 8697-8699; (h) Álvarez, M.; Fernández, D.; Joule, J. A. Tetrahedron Lett. 2001, 42, 315-317; (i) Anderson, R. J.; Morris, J. C. Tetrahedron Lett. 2001, 42, 311-313; (j) Fresneda, P. M.; Molina, P.; Delgado, S.; Bleda, J. A. Tetrahedron Lett. 2000, 41, 47774780 .

5. (a) Mendiola, J.; Castellote, I.; Alvarez-Builla, J.; Fernández-Gadea, J.; Gómez, A.; Vaquero, J. J. J. Org. Chem. 2006, 71, 1254-1257; (b) Baeza, A.; Mendiola, J.; Burgos, C.; Álvarez-Builla, J.; Vaquero, J. J. J. Org. Chem. 2005, 70, 4879-4882; (c) Mendiola, J.; Baeza, A.; Alvarez-Builla, J.; Vaquero, J. J. J. Org. Chem. 2004, 69, 4974 4983; (d) Mendiola, J.; Mínguez, J. M.; Álvarez-Builla, J.; Vaquero, J. J. Org. Lett. 2000, 2, 3253-3256; (e) Mínguez, J. M.; Vaquero, J. J.; Álvarez-Builla, J.; Castaño, O.; Andrés, J. L. J. Org. Chem. 1999, 64, 7788-7801.

6. (a) Houwing, H. A.; Wildeman, J.; van Leusen, A. M. J. Heterocycl. Chem. 1981, 18, 1133-1139; (b) Houwing, H. A.; Wildeman, J.; van Leusen, A. M. Tetrahedron Lett. 1976, 143-146; (c) Olijnsma, T.; Engberts, J. B. F. N. Synth. Commun. 1973, 3, 1-8.
7. General procedure for the preparation of azolopyrimidines $\mathbf{8}$ and 9: A mixture of bromomethylazole 3a,b $(2.8 \mathrm{mmol})$, $N$-tosylmethyl dichloroformimide ${ }^{6 \mathrm{~b}} 6(0.821 \mathrm{~g}, 3.1 \mathrm{mmol})$, TBACl ( $80 \mathrm{mg}, 0.28 \mathrm{mmol})$ in $\mathrm{CH}_{2} \mathrm{Cl}_{2}(30 \mathrm{~mL})$ and $30 \%$ $\mathrm{LiOH}(30 \mathrm{~mL})$ was stirred at room temperature for $5 \mathrm{~h}$. The reaction mixture was poured into water and extracted with $\mathrm{CH}_{2} \mathrm{Cl}_{2}$. The organic phase was washed with brine, dried $\left(\mathrm{Na}_{2} \mathrm{SO}_{4}\right)$ and concentrated under reduced pressure to give a crude product, which was chromatographed on silica gel [hexanes/EtOAc (8:2)] to yield pure compounds 8 and 9.

8. (a) Huang, X.; Buchwald, S. L. Org. Lett. 2001, 3, 34173419; (b) Lee, S.; Jorgensen, M.; Hartwig, J. F. Org. Lett. 2001, 3, 2729-2732; (c) Wolfe, J. P.; Tomori, H.; Sadighi, J. P.; Yin, J.; Buchwald, S. L. J. Org. Chem. 2000, 65, 1158-1174; (d) Hartwig, J. F.; Kawatsura, M.; Hauck, S. I.; Shaughnessy, K. H.; Alcazar-Román, L. M. J. Org. Chem. 1999, 64, 5575-5580; (e) Hartwig, J. F. Angew. Chem., Int. Ed. 1998, 37, 2046-2067.

9. Huang, X.; Anderson, K. W.; Zim, D.; Jiang, L.; Klapars, A.; Buchwald, S. L. J. Am. Chem. Soc. 2003, 125, 66536655.

10. Experimental procedure for the preparation of 9-aminoderivatives 10a and 11a: A solution of LiHMDS in THF $(1.0 \mathrm{M}, 1.2 \mathrm{~mL}, 1.2 \mathrm{mmol})$ was added dropwise to a mixture of azolopyrimidine $(\mathbf{8}$ or 9$)(1.0 \mathrm{mmol})$, triphenylsilanylamine $\quad(0.330 \mathrm{~g}, \quad 1.2 \mathrm{mmol}), \quad \mathrm{Pd}_{2}(\mathrm{dba})_{3}$ $(18 \mathrm{mg}, \quad 0.02 \mathrm{mmol})$ and (2-biphenyl)di-tert-butylphosphine $(12 \mathrm{mg}, 0.04 \mathrm{mmol})$ in dry THF $(10 \mathrm{~mL})$ under an atmosphere of dry argon. The resulting mixture was stirred at room temperature for $16 \mathrm{~h}$ and then poured into water and extracted with $\mathrm{CH}_{2} \mathrm{Cl}_{2}$. The organic phase was washed with brine, dried $\left(\mathrm{Na}_{2} \mathrm{SO}_{4}\right)$ and concentrated under reduced pressure to give a crude product, which was chromatographed on silica gel $\left[\mathrm{CH}_{2} \mathrm{Cl}_{2} /\right.$ acetone (9:1)] to yield pure compounds 10a and 11a.

11. General procedure for the amination of $\mathbf{8}$ and 9: The corresponding substituted amine $(1.2 \mathrm{mmol})$ was added to a mixture of azolopyrimidine $(8$ or 9$)(1.0 \mathrm{mmol}), \mathrm{NaO}^{t} \mathrm{Bu}$ $(0.135 \mathrm{mg}, 1.4 \mathrm{mmol}), \mathrm{Pd}(\mathrm{OAc})_{2}(11 \mathrm{mg}, 0.05 \mathrm{mmol})$, and (2-biphenyl)di-tert-butylphosphine $(30 \mathrm{mg}, 0.1 \mathrm{mmol})$ in dry THF $(10 \mathrm{~mL})$ under an atmosphere of dry argon. The resulting mixture was heated at $70{ }^{\circ} \mathrm{C}$ for $12 \mathrm{~h}$ and the reaction mixture was poured into water and extracted with $\mathrm{CH}_{2} \mathrm{Cl}_{2}$. The organic phase was washed with brine, dried $\left(\mathrm{Na}_{2} \mathrm{SO}_{4}\right)$ and concentrated under reduced pressure to give a crude product, which was chromatographed on silica gel $\left[\mathrm{CH}_{2} \mathrm{Cl}_{2}\right.$ /acetone (9:1)] to yield pure compounds $\mathbf{1 0 b}-\mathbf{l}$ and 11b-l. 